\title{
WINTER IS COMING: THE BARBARIZATION OF ROMAN LEADERS IN IMPERIAL PANEGYRIC FROM A.D. 446-68 ${ }^{1}$
}

The Ostrogothic king Theoderic I (A.D. 475-526) drew on his experience of ruling postimperial Italy when he famously remarked that 'The poor Roman imitates the Goth and the rich Goth imitates the Roman'. ${ }^{2}$ Written well after the fall of the western Roman empire, these words have prefaced many discussions of the process of Roman and barbarian assimilation and mutual acculturation. This topic has long captured the imagination of scholars, who have approached the topic from many different angles, such as archaeology, religion, prosopography and literature. ${ }^{3}$

While scholarship has considerably advanced our understanding of how Romans and barbarians interacted in the real world, less attention has been paid to shifts in rhetoric and ideology brought about by this exchange. Most explorations of Latin intellectual discourse have tended to focus almost exclusively on how Romans rhetorically Romanized barbarian leaders, especially after the fall of the empire. ${ }^{4}$ For example,

\footnotetext{
${ }^{1}$ In the course of writing this paper, I have incurred a debt of gratitude to a number of scholars. First, my thanks are due to Anthony Kaldellis and the other students of his seminar on Constantinople in Fall 2015, from which this paper ultimately derives. I greatly appreciated Kaldellis's patience and editorial forbearance as a paper originally on western Roman views of Constantinople morphed into its present form. I am also grateful to the students of Ohio State's coffee hour, who graciously allowed me to present a condensed version of this paper. Finally, my thanks are due to Bruce Gibson and the anonymous reviewers of $C Q$, whose comments and corrections greatly improved this paper. However, all errors are my own.

${ }^{2}$ Anonymus Valesianus 12.61: Romanus miser imitatur Gothum et utilis Gothus imitatur Romanum. The text is edited by I. König, Aus der Zeit Theoderichs des Großen. Einleitung, Text, Übersetzung und Kommentar einer anonymen Quelle (Darmstadt, 1997). All translations are my own.

${ }^{3}$ The bibliography on this topic is expansive. This is only a selection of some important contributions and collections on the issue: Y. Hen, Roman Barbarians: The Royal Court and Culture in the Early Medieval West (New York, 2007), 27-123; W. Pohl, Kingdoms of the Empire: The Integration of Barbarians in Late Antiquity (Leiden, 1997); W. Pohl and H. Reimitz, Strategies of Distinction: The Construction of Ethnic Communities, 300-800 (Leiden, 1998); R.W. Mathisen and D. Shanzer, Romans, Barbarians, and the Transformation of the Classical World (Burlington, VT, 2011); J. Conant, Staying Roman: Conquest and Identity in Africa and the Mediterranean, 439-700 (Cambridge, 2012); W.A. Goffart, Barbarians and Romans, A.D. 418-584: The Techniques of Accommodation (Princeton, NJ, 1980); P. Brown, The Rise of Western Christendom: Triumph and Diversity, A.D. 200-1000 (Oxford, 2003); P. Courcelle, Histoire littéraire des grandes invasions germaniques (Paris, 1964).

${ }^{4}$ L. Watson, 'Representing the past, redefining the future: Sidonius Apollinaris' panegyrics of Avitus and Anthemius', in M. Whitby (ed.), The Propaganda of Power: The Role of Panegyric in Late Antiquity (Leiden, 1998), 177-98, at 191-2; P. Heather, The Fall of the Roman Empire: A New History (London, 2005), 381; J. Harries, 'Sidonius Apollinaris, Rome and the barbarians: a climate of treason?', in J. Drinkwater and H. Elton (edd.), Fifth Century Gaul: A Crisis of Identity (Cambridge, 1992), 298-308, at 299-300; J. Arnold, Theoderic and the Roman Imperial Restoration (Cambridge, 2014), 121-41; J. Conant, 'Romanness in the age of Attila', in M. Maas (ed.), The Cambridge Companion to the Age of Attila (Cambridge, 2014), 156-74, at 166-7.
} 
Arnold has recently shown how Theoderic I positioned his regime as the continuation and revival of the western Roman empire under the aegis of the Ostrogoths. ${ }^{5}$

But comparatively little work has been done on the Roman side of the barbarian-Roman divide. There has been some exploration of intellectuals' perceptions of the Roman adoption of barbarian customs and even 'de-Romanization', 6 but this area is still less well understood than one might hope. Scholarship has focussed primarily on Romans after the discontinuation of native Roman rule. In contrast, this article explores the trend toward barbarizing Roman leaders in verse panegyrics written by Flavius Merobaudes and Sidonius Apollinaris shortly before the end of Roman rule. ${ }^{7}$

The panegyric of an emperor or general offered an ideal opportunity to propagate a desired image of leadership to the western court. Often delivered before members of the imperial court, Senate, army and foederati, such discourse was a vehicle for broadcasting the honorand's merits as a leader and proving that he had the mettle to command Rome's armies. ${ }^{8}$ Writing in a formulaic genre, panegyrists had to work with existing Roman topoi of leadership, but they could also rework them. It was a genre full of stereotypes and racial assumptions, as a leader had to represent his Romanness properly in terms of existing constructs of barbarity and non-Romanness. Through a close examination of Sidonius and Merobaudes in the light of earlier panegyrical topoi, this article argues that Roman propagandists in the mid fifth century redefined traditional constructs of Roman military leadership, casting their leaders in ways that were traditionally associated with 'northern' barbarians. ${ }^{9}$

\section{THE CONFLUENCE OF ROMAN ENVIRONMENTAL THEORY AND PANEGYRIC}

To understand the development in question, we must begin with Roman racial-environmental constructs. In Roman intellectual circles, racial stereotypes for northerners and southerners were determined in part by environmental theory, which stressed the influence of heat and cold on the human body. The dichotomy was hardly new, as Greek intellectuals such as Herodotus and Hippocrates had included climate as a factor that determined the character of a people. ${ }^{10}$ Aristotle had developed the concept

5 Arnold (n. 4).

${ }^{6}$ Arnold (n. 4), 235-61; Courcelle (n. 3), 235-52.

7 On late imperial panegyrics, see R. Rees, Latin Panegyric (Oxford, 2012), 3-48; R. Rees, Layers of Loyalty in Latin Panegyric: A.D. $289-307$ (Oxford, 2002); C. Schindler, Per carmina laudes: Untersuchungen zur spätantiken Verspanegyrik von Claudian bis Coripp (Berlin, 2009); M. Mause, Die Darstellung des Kaisers in der lateinischen Panegyrik (Stuttgart, 1994); S. MacCormack, 'Latin prose panegyrics: tradition and discontinuity in the later Roman empire', REAug 22 (1976), 29-77.

${ }^{8}$ On the ceremony as propaganda, Mause (n. 7), 30-42; A. Cameron, Claudian: Poetry and Propaganda at the Court of Honorius (Oxford, 1970).

9 J. Weisweiler, 'From empire to world-state: ecumenical language and cosmopolitan consciousness in the later Roman aristocracy', in M. Lavan, R.E. Payne and J. Weisweiler (edd.), Cosmopolitanism and Empire: Universal Rulers, Local Elites, and Cultural Integration in the Ancient Near East and Mediterranean (Oxford, 2016), 201-4 detects a similar kind of hypermasculine northern type emerging in Symmachus' panegyric of Valentinian I. However, I would point out that Symmachus also emphasizes Valentinian's endurance of the cold (Symm. Orat. 1.1, 2). It is only starting with Merobaudes' panegyric of Aetius that the northern barbarian type takes over.

${ }^{10}$ On environmental theory and its development, see Y.A. Dauge, Le Barbare. Recherches sur la conception romaine de la barbarie et de la civilisation (Brussels, 1981), 468-81 and especially 
further in his Politics, positing that Europeans living in a cold climate were warlike and full of spirit, but lacked the intelligence to rule. Asians in contrast were intelligent, but lacked spirit and thus were also unsuited to rule. Greece with its moderate climate could offer the best of both worlds in terms of intelligence and spirit. If the squabbling Greeks could unite, they could rule the world (Arist. Pol. 7.7).

This formulation of environmental and racial theory had a lasting and widespread impact on later Roman thought. In the Roman adaptation of the Greek model, North and South, or hot and cold, rather than Asia and Europe, became the polar dichotomies through which Romans understood foreign peoples. Southerners could easily withstand the heat, but they were more cunning and lacked the physical strength necessary for war, because the sun dried up their blood or spirit. In contrast, northerners had too much of these and were prone to war, but lacked good counsel. Unsurprisingly, Rome, with its temperate climate, was celebrated for striking the perfect balance between the intellectual and physical extremes and defects of its opponents. For Roman authors before the reign of Valentinian III (A.D. 425-55), this balance was what enabled it to conquer the world. In effect, it had succeeded where Aristotle's squabbling Greece had failed. Writing in the first century B.C., Vitruvius most clearly elaborated this thesis, arguing that Rome had exploited its enemies' fundamental imbalance, overwhelming northerners with clever stratagems and overcoming southerners with physical force (De arch. 6.1.4, 9-10). Indeed, Vegetius' De re militari, reflecting the advice of earlier Roman military treatises, recommends recruiting Roman soldiers from the more temperate regions of the world, so that they would possess an ideal balance of intelligence and strength as soldiers. ${ }^{11}$

If Rome's soldiers needed this balance, their commanders and especially their commander-in-chief needed it most. As early as Cato the Elder, we find a father teaching his son to endure the hot and the cold (Plut. Cat. Mai. 20.6). Latin panegyrics frequently discuss a military man's endurance of the heat and cold. ${ }^{12}$ Starting with Pliny the Younger's panegyric of Trajan, this trope was deemed a necessary component of a commander's fortitudo (strength) that proved his right to rule and command the army. ${ }^{13}$ For example, when Valentinian I (364-75) sought to elevate his son Gratian to the purple, he realized that Gratian was a weak candidate because he lacked a proper military background. In his purported address to the army in Ammianus Marcellinus, Valentinian concedes that Gratian lacked a tough upbringing that would have taught him to tolerate bitter elements as his father could, but he promised that he would teach his son to endure the sun and the snow (solem niuesque ... perferet). ${ }^{14}$ Whether Valentinian actually said this does not really matter: the passage clearly demonstrates how widely desirable this balance of hot and cold was in Roman military thought. Roman emperors and their panegyrists found it necessary to advertise this credential to their subjects even when an emperor lacked a military upbringing or spent his entire

B. Isaac, The Invention of Racism in Classical Antiquity (Princeton, NJ, 2004), 55-168. M.M. Sassi, The Science of Man in Ancient Greece (Chicago, 2001), 82-139 is also helpful.

${ }^{11}$ Veg. Mil. 1.2. Vegetius tells us that his information on recruitment had been approved by the most learned men (quae a doctissimis hominibus conprobata sunt).

12 Concerning a monarch: Plin. Pan. 12.3-4; Symm. Orat. 1.1, 2; Amm. Marc. 25.4.10, 27.6.8-9; Claud. 3 Cons. 44-5; Ennodius, Panegyricus 7, 9. Concerning a commander: Livy, Epit. 21.4; Pan. Lat. 11(2).8.3; Claud. Ruf. 1.241-2; 4 Cons. 26-40. Concerning soldiers: Claud. Stil. 1.176-90.

${ }^{13}$ Plin. Pan. 15.3-4. On this topos, cf. Mause (n. 7), 79; G. Posset, 'Studien zur panegyrischen Topik in den Panegyrici Latini bis zum Jahre 313' (Diss., Vienna, 1991), 35-40.

14 Amm. Marc. 27.6.8. 
life in the palace. For example, Claudian reports that Theodosius taught Honorius to endure the cold and the heat, thus endowing his addressee with this required leadership trait even if Honorius never led an army in his life (3 Cons. 44-5). When a Roman aristocrat was portrayed lacking this balance, it was often a sign of trouble, as in the case of Sallust's Catiline, whose 'body's endurance of hunger, cold, and a lack of sleep went beyond what one would believe' (Cat. 5.3). Describing Catiline also as bold (audax) and mercurial (uarius), Sallust encoded Catiline within the stereotypes of northern barbarians who could endure the cold and were full of spirit, but ultimately lacked moderation (Cat. 5.4).

While Roman power still dominated the Mediterranean, this ideological model held sway. Panegyrists could delight when an emperor such as Constantine the Great used clever stratagems to outwit credulous northern barbarians. ${ }^{15}$ However, crippling barbarian victories and an army increasingly dominated by barbarians undermined this proto-racist construct. ${ }^{16}$ Although Romans could always surpass barbarians intellectually and would continue to celebrate their intellectual superiority even after the demise of the western empire, ${ }^{17}$ they now wondered whether their physical strength was adequate to defeat their northern enemies. Writing between 439 and $451,{ }^{18}$ Salvian of Marseille complained: 'If we are equal in vice to the barbarians, why are we not equal in strength? Since their shamelessness is similar and their culpability the same, we either ought to be just as strong as they are, or more precisely they ought to be just as weak as we are' (De gubernatione Dei 4.14). In the past, Roman panegyrists might have celebrated a leader's balanced virtues, but in the western empire's final years they reconfigured existing tropes in order to praise their emperors in ways appropriate to the new situation, by embracing the extreme virtues of the frozen north, the source of the most troublesome barbarians the West was facing. It became increasingly important for their leaders to surpass barbarians in areas where barbarians excelled to prove that their commanders had the mettle to defeat barbarian opponents and command the respect of barbarian troops.

${ }^{15}$ Pan. Lat. 9(4).18.3-4. Similarly, Hdn. 6.3.7.

${ }^{16}$ The barbarian and native composition of the Roman army has been the subject of much debate, especially with regard to the years before Valentinian III (425-55). Scholars such as M. Nicasie, Twilight of Empire: The Roman Army from the Reign of Diocletian until the Battle of Adrianople (Leiden, 1998), H. Elton, Warfare in Roman Europe, A.D. 350-425 (Oxford, 1996) and T.S. Burns, Barbarians within the Gates of Rome: A Study of Roman Military Policy and the Barbarians, ca. 375-425 A.D. (Bloomington, IN, 1994) have generally argued that the barbarians made up only a small component of the late Roman army. However, there seems to be wider acceptance that the army from Valentinian onward relied much more heavily on barbarians acting independently of the imperial service. W. Liebeschuetz, 'The end of the Roman army in the western empire', in J. Rich and G. Shipley (edd.), War and Society in the Roman World (London, 1993), 265-76 and E. James, Europe's Barbarians, A.D. 200-600 (Harlow, 2009), 171-3 argue that the army relied almost exclusively on coalitions of barbarians from the 450 s onward.

${ }^{17}$ R.W. Mathisen, 'Violent behavior and the construction of barbarian identity', in H.A. Drake (ed.), Violence in Late Antiquity: Perceptions and Practices (Burlington, VT, 2006), 27-35, at 34-5; R.W. Mathisen, Roman Aristocrats in Barbarian Gaul: Strategies for Survival in an Age of Transition (Austin, TX, 1993).

${ }^{18}$ On Salvian, see D. Lambert, 'The uses of decay: history in Salvian's De gubernatione Dei', AugStud 30 (1999), 115-30; R. Alciati, Monachi, vescovi e scuola nella Gallia tardoantica (Rome, 2009), 83-101; P. Brown, Through the Eye of a Needle: Wealth, the Fall of Rome, and the Making of Christianity in the West, 350-550 A.D. (Princeton, 2012), 441-53; Courcelle (n. 3), 146-55. 


\section{THE END OF THE PERFECT BALANCE}

The first text in which we can note this shift is Merobaudes' panegyric in honour of the general Aetius' consulship in A.D. 446. Like many panegyrists, Merobaudes includes a flashback on Aetius' youth, in which the so-called 'last of the Romans' (Procop. Hist. 5.3.14) looks more like a young barbarian than like a Roman:

\begin{abstract}
ut uix prona nouis erexit gressibus ora primaque reptatis niuibus uestigia fixit, mox iaculum petiere manus lusitque gelatis imbribus et siccis imitatus missile lymphis temptauit pugnas tenerosque ad proelia ludos imbuit et ueras iam tunc respexit ad hastas.
\end{abstract}

... No sooner had he [baby Aetius] raised up his downward-facing head and taken his first steps, leaving his first footprints in the snow over which he had previously crawled, than his hands soon sought a spear. He played with frozen rain and fashioned the icy water into a missile with which he attempted to do combat. He gained his first experience in war from these childhood games (125), even then having his eyes on real spears. ${ }^{19}$

As we have seen, it was quite common to stress an emperor's endurance of heat and cold alike in panegyrics before Merobaudes. Roman anthropology saw this tolerance of climatic extremes as a fundamental part of what defined an ideal Roman predominance. But from Aetius onward, panegyrists reconfigured this construct. Instead of emphasizing Aetius' balanced endurance of heat and cold, Merobaudes focusses exclusively on his subject's extreme endurance of the cold, and from a very young age at that. Aetius did not train to endure the cold when he was already a fully formed Roman: he was shaped by it from the start. Aetius' youthful first steps in the snow hearken back to Roman and Greek stereotypes of northern barbarians, who dunked their young children in icy river waters as a trial of strength. If the child survived this frigid baptism, they were deemed worth living (Sor. Gyn. 2.12; Gal. De san. tuen. 6.51). But baby Aetius is even more extraordinary than a barbarian child. He crawls and then walks through the snow of his own apparent volition! This icy anecdote would have been quite extraordinary for Roman audiences. To be sure, Romans prided themselves on their endurance of the cold. For example, the late Emperor Theodosius personified by Claudian tells Honorius to trample the icy river and swim in it when it melted (Claud. 4 Cons. 347-8). But Roman tolerance of the cold had its limits and generally did not surpass that of northern barbarians. Romans had to yield to barbarians when it came to an extreme endurance of the cold. For example, Pliny the Younger describes barbarians repeatedly crossing the frozen Danube in the middle of winter, which was a time 'most friendly for them, but most difficult for us' (Plin. Pan. 12.3-4). Similarly, Claudian calls winter the ally of Alaric (A.D. 395-410) when he invaded Italy in 401, elsewhere comparing the Goths to a hailstorm (Claud. 6 Con. 444-5; Get. 174). But after Aetius, Roman panegyrists make winter the ally of their own leaders, and in Aetius' case their playground.

Merobaudes' young Aetius is not only better at enduring the cold than any previous commander, he is also more warlike. In Roman panegyrics, it is relatively common to talk about how a general was exposed to war at a young age. For example, Claudian

${ }^{19}$ Merobaudes, Panegyric 2.121-6. Merobaudes is cited according to F.M. Clover, 'Flavius Merobaudes: a translation and historical commentary', TAPhS 61 (1971), 1-78. 
recounts how Honorius learned to crawl among shields and played with the spoils of vanquished enemies as a young child. Indeed, when his father Theodosius returned from war, Honorius did not fear his father's helmet, as Hector's infant son Astyanax had in $\mathrm{Il}$. 6.466-70, but rather reached out to grab its plume. ${ }^{20}$ Nevertheless, Claudian tells us that Theodosius forbade his eager child from engaging in war until after he had completed his education (4 Cons. 369-87). But the panegyrists of Rome's final years made this topos even more extreme, rendering their leaders more bellicose than their predecessors, and more similar to barbarians. The world of Claudian has been transferred to tough ice and snow in Merobaudes. ${ }^{21}$ His Aetius is not just playing among shields and admiring his father's armour. His first impulse is to craft a spear from ice and hurl it at other little boys until he is old enough to get his hands on the real thing. Barbaric peoples were known for practising war from a very young age. ${ }^{22}$ While youthful bellicosity was not the exclusive preserve of barbarians, Merobaudes renders this toddler's propensity for war more extreme than that of any previous commander.

But Aetius' youthful bellicosity serves an important purpose in his panegyric. In order to counter fears that Romans were not strong enough to defeat barbarians, Merobaudes introduces the following scene to his panegyric directly after describing the baby Aetius (Panegyric 2.133-43):

... stupuere feroces
in tenero iam membra Getae. rex ipse uerendum
miratus pueri decus et prodentia fatum
lumina primaeuas dederat gestare pharetras
laudabatque manus librantem et tela gerentem
oblitus quod noster erat. pro nescia regis
corda, feris quanto populis discrimine constat
quod Latium docet arma ducem! sed nomine natum
nuncupat et mauult naturae dicere pignus
quam pacis. tali teneros sub iudice primum
gaudebat studiis flammare ferocibus annos ...

Already the Getae [Goths] were astonished at the limbs of one so young. After admiring the fearsome dignity of the boy (135) and his eyes that indicated his destiny, their king himself [that is, Alaric I (395-410)] gave him his first quiver to wear and praised him for how he poised his arms and handled a spear, forgetting that he was one of us. How ignorant their king was in his heart of what a danger it would pose for savage peoples to teach the Roman leader the art of war. But in name he calls him 'son' (140), and prefers to speak of a pledge of nature rather than peace. It was under such a judge that Aetius first rejoiced in setting his youthful years on fire with warlike pursuits ...

This scene cleverly shows why Aetius had the virtues to defeat the barbarians: he passed as one of them and had learned their ways from an early age. But, crucially, Merobaudes also makes Aetius superior to the barbarians who raised him. For example, the Goths marvel at his youthful limbs. Northerners by nature had strong limbs because of their environment. Exposure to the cold was commonly presumed to strengthen a child's limbs. ${ }^{23}$ The baby Aetius' first steps in the snow and his icicle games would therefore

${ }^{20}$ Claud. 3 Cons. 22-32. Similarly, Pan. Lat. 1(10).2.4; Symm. Orat. 1.1; Claud. 4 Cons. 149-53, 160-4.

21 Schindler (n. 7), 177.

22 Sid. Apoll. Carm. 5.249-50; Verg. Aen. 6.606-7; Caes. BGall. 4.1.10.

23 Tac. Germ. 4; Caes. BGall. 4.1.10; Gal. De san. tuend. 6.51; Sid. Apoll. Carm. 7.171-2, 2.37. 
have developed strong limbs but in a man with a Roman mind. Thus, having the Goths, who were already strong-limbed by nature, admire Aetius' limbs shows the general's superior strength and that he can 'outbarbarian' the barbarian. This kind of scene was not unprecedented in Roman panegyric. For example, Claudian makes the Persians admire the semi-barbarian Stilicho's skill at riding on horseback and drawing a bow (Stil. 1.64-8), skills at which the Persians were deemed to excel. Stilicho is a complex example, as some Romans alleged he was of Vandal descent, but he is treated as a typical Roman commander in Claudian. ${ }^{24}$ However, in Merobaudes, the Roman no longer excels on his own in military skill. He learns from the barbarians and eventually surpasses them.

\section{ROMAN LEADERS AFTER AETIUS}

To establish a Roman ruler's credentials to master the troubled world of the fifth century, it gradually became necessary to show a more extreme and often barbarian-like endurance of the cold and a youthful bellicosity, which enabled him to beat the barbarians at their own game. Increasingly, a leader's superior strength also had to be externally verified by barbarians. ${ }^{25}$ One could argue that Merobaudes' portrayal of Aetius was exceptional. Aetius had after all grown up in Pannonia and spent his adolescence at the court of the Gothic king Alaric, so Merobaudes was adapting Roman virtues and tropes to this particular occasion. But his portrait is none the less significant. Merobaudes could simply have portrayed Aetius as a barbarian among Romans or even could have omitted his barbarian upbringing, if this content would have weakened his portrait of the Roman commander.

Nevertheless, his portrayal of Aetius as a barbarized Roman leader caught on in later panegyric. Aetius was widely recognized for his great accomplishments in holding the empire together. After controlling the empire for over twenty years, many members of the army had fought with him. Some probably even owed him their careers. Similarly, the need to establish one's superiority to the barbarians on the latter's terms did not go away in subsequent years, as noted barbarian leaders such as Ricimer continued to dominate the army. ${ }^{26}$ Thus, later panegyrics of the Emperors Avitus, Majorian and Anthemius written by the Gallo-Roman aristocrat and intellectual Sidonius Apollinaris incorporated these same elements in varying degrees, blending traditional Roman discourse with this discourse. ${ }^{27}$

For example, in his panegyric in honour of his father-in-law Avitus, delivered before the Roman Senate in January 456, Sidonius incorporates Merobaudes' image of a leader learning to endure cold in infancy. Like a barbarian father dunking his child in an icy river, Avitus' father allegedly made his baby son walk over ice, break it down with

24 On the portrayal of Stilicho as a typical Roman commander in Claudian, see Á. Sánchez-Ostiz, 'Claudian's Stilicho at the Vrbs: Roman legitimacy for the half-barbarian regent', in D.W.P. Burgersijk and A.J. Ross (edd.), Imagining Emperors in the Later Roman Empire (Leiden, 2018), 310-30.

${ }^{25}$ Cf. Liebeschuetz (n. 16), 275.

26 On Ricimer, see J. O'Flynn, Generalissimos of the Western Roman Empire (Edmonton, 1983), 104-28; P. MacGeorge, Late Roman Warlords (Oxford, 2003), 167-278.

27 On Sidonius, the bibliography is vast. For a starting point, see J. Harries, Sidonius Apollinaris and the Fall of Rome: A.D. 407-485 (Oxford, 1994); A. Loyen, Recherches historiques sur les panégyriques de Sidoine Apollinaire (Paris, 1942). For more detail, see https://sidonapol.org/. 
his bare feet, and laugh at the trampled ice in order to harden and strengthen his son (Carm. 7.171-2). Gone is any mention of Avitus' corresponding endurance of the heat. Only the cold prevails here. Similarly, Sidonius celebrates the early martial qualities of Avitus as a hunter and horseback rider (Carm. 7.177-82). For example, Sidonius recounts that Avitus was scarcely a boy when he brought down a ravenous she-wolf with a stone. As the text subsequently makes clear, this act symbolizes Avitus' superiority over the barbarians, as the Visigoths seeking to capitalize on Aetius' death are described as ravenous wolves hunting for sheep (Carm. 7.362-8). But the key Aetian quality with which Sidonius endows his portrayal of Avitus is how barbarians admired and embraced Avitus. For example, Sidonius has the Visigothic king Theoderic II (453-66) marvel at Avitus and try to win him over to his side (Carm. 7.219-24). Similarly, when Avitus joins Aetius' army in 430-1, Sidonius marvels at how he surpassed all of the barbarian tribes in their various arts, including the Huns in javelin-throwing (Carm. 7.230-40). Thus, Avitus, while still Roman, is raised in harsh conditions and outperforms the barbarians in qualities that used to be distinctive to them.

In his panegyric of Majorian, Sidonius avoids mentioning the emperor's childhood and upbringing. He puts an account of Majorian's virtues in the mouth of Aetius' barbarian wife, which hits upon similar topoi as we find in the other panegyrics. We note Majorian's 'game' of bringing animals down with his bow while hunting, his superiority on horseback, and his preference for bathing in the icy cold rivers of Gaul (Sid. Apoll. Carm. 5.151-4, 177-81, 207-8). The former qualities are typical of a Roman aristocrat, but the last one harkens back to ancient stereotypes of Germans. For example, Caesar recounts that the German Suebi used to bathe in ice-cold river water in order to strengthen themselves. ${ }^{28}$ Sidonius even offers proof that this endurance of the cold comes from Majorian's ancestors. When praising Majorian's grandfather and namesake, Sidonius recounts that he inspired his troops to mock the cold and bid welcome to the frost (Carm. 5.112-15). Put in the mouth of Aetius' wife, whom Sidonius explicitly labels a barbarian (Carm. 5.128), her admiration for his martial virtues provides implicit barbarian verification of Roman strength. But, for good measure, Sidonius includes a more explicit scene, demonstrating that Majorian surpassed the barbarians. It comes when Majorian crossed the rugged icy Alps on his way to Gaul in December 458.

Portraying a commander crossing the Alps during wintry weather was a common scene in Latin literature, as exemplified most vividly by Livy's account of Hannibal's march across the Alps in Fall 218 B.C. ${ }^{29}$ It was often deployed in imperial panegyrics to show how emperors swiftly overcame the frigid terrain. ${ }^{30}$ In Sidonius, it serves this purpose, but it is also carefully constructed to show the emperor's superiority over the barbarians. As the emperor eagerly leads the march through a snowstorm, Sidonius has a Scythian in the emperor's army exclaim in frustration that he would rather die than continue his march. He queries what people bore Majorian, if even a Scythian cannot keep up with his progress through the snow (qua dicam gentem

${ }^{28}$ Caes. BGall. 4.1.10.

29 Livy, Epit. 21.31-58; Petron. Sat. 122-3; Sil. Pun. 3.477-556; Luc. 1.183.

${ }^{30}$ Plin. Pan. 14.2-3; Pan. Lat. 3(11).9, 9(12).3.3, 12(2).45.2. On this scene in Sidonius, see T. Brolli, 'Silio in Sidonio: Maggioriano e il passagio delle Alpe', Incontri triestini di filologia classica 3 (2003-4), 297-314. 
[sc. Maiorianum] creatum | quem Scytha non patior) $?^{31}$ Thus, Majorian exceeds the Scythian in what should have been the Scythian's proper domain. Sidonius also sends a message to the barbarians in the army and abroad through his Scythian mouthpiece. When the Scythian complains that he thought serving Rome's emperors would be easy because they were more luxurious and lazy than northern kings (Carm. 5.534-8), Sidonius craftily announces the restoration of Rome's dominance. Her emperors will lead their Roman and barbarian troops to war and even surpass the latter at stereotypically barbarian activities.

\section{THE EMPEROR'S NEW FURS}

The barbarization of the Roman emperor reaches its pinnacle in Sidonius' panegyric of the Emperor Anthemius (467-72). Delivered in January 468, less than a decade before the western empire's end, this text goes out of its way to wrap an eastern aristocrat in a barbarian's fur skins. Anthemius was an outsider to the western Roman establishment. He was born to a patrician family in Constantinople, serving the eastern empire as magister militum until the eastern emperor Leo I (457-74) elevated him to the western throne. ${ }^{32}$ For some in the western establishment, the imposition of an eastern magnate must have been quite unwelcome. Some western Romans disdainfully cast their eastern compatriots as 'Greeklings' steeped in luxury and effeminacy. ${ }^{33}$ Sidonius, however, avoids these tropes, carefully normalizing Anthemius for the westerners, and that by now meant barbarizing him.

Perhaps the most vivid sign of this approach is Sidonius' portrayal of Constantinople, Anthemius' birthplace. Originally founded by Greeks and later refounded as a second capital of the Roman empire by Constantine the Great (306-37), Constantinople was one of the most civilized cities in the world at this point in history. Discussing the city, previous Latin authors had highlighted its foundation by Constantine or its Greek heritage. ${ }^{34}$ But Sidonius went in an entirely new direction. He does discuss the city's prosperity and temperate weather, but he completely omits its Constantinian or Greek origins. Instead, he focusses on its connections with the ancient Thracians,

31 Carm. 5.529-30.

32 On Anthemius, D. Henning, 'Der erste ,griechische Kaiser”. Überlegungen zum Scheitern des Procopius Anthemius im weströmischen Reich', in H.U. Wiemer (ed.), Staatlichkeit und politisches Handeln in der römischen Kaiserzeit (Berlin, 2006), 1-40; J. O'Flynn, 'A Greek on the Roman throne: the fate of Anthemius', HZ 40 (1991), 122-8.

${ }^{33}$ Some westerners labeled Anthemius a Greek. Sid. Apoll. Epist. 1.7.5 reports that the Gallic praetorian prefect Arvandus conspired with the Gothic king Euric (466-84) to dethrone the 'Greek' emperor. Similarly, in Ennodius, Life of Epiphanius 54, Anthemius is deemed a Graeculus by the Ligurian nobility. (Ennodius is cited according to the edition of G.M. Cook, The Life of Saint Epiphanius by Ennodius: A Translation with an Introduction and Commentary [Washington, D.C., 1942].) For a helpful summary of Roman prejudices against Greeks, Isaac (n. 10), 381-405; Dauge (n. 10), 546-54; N. Petrochilos, Roman Attitudes to the Greeks (Athens, 1974); J.P.V.D. Balsdon, Romans and Aliens (London, 1979), 30-54.

${ }^{34}$ E. Fenster, Laudes Constantinopolitanae (Munich, 1968), 20-54. On Sidonius' image of Byzantium, M. Bonjour, 'Sidoine Apollinaire et 1'Empire', in La patrie gauloise d'Agrippa au VIème siècle: actes du colloque (Lyon 1981) (Lyon, 1983), 203-18; G. Kelly, 'Sidonius and Claudian', in J.A. van Waarden and G. Kelly (edd.), New Approaches to Sidonius Apollinaris (Leuven, 2013), 171-93; Schindler (n. 7), 200-1. 
who lived in the vicinity of the Greek city. ${ }^{35}$ But these are no Thracians, whom ancient or modern scholars would recognize. Addressing Constantinople personified, Sidonius writes (Carm. 2.30-46):

... Rhodopen quae portat et Haemum,

Thracum terra tua est, heroum fertilis ora.

excipit hic natos glacies et matris ab aluo

artus infantum molles nix ciuica durat.

pectore uix alitur quisquam, sed ab ubere tractus

plus potat per uulnus equum; sic lacte relicto

uirtutem gens tota bibit. creuere parumper:

mox pugnam ludunt iaculis; hos suggerit illis

nutrix plaga iocos; pueri uenatibus apti

lustra feris uacuant, rapto ditata iuuentus

iura colit gladii, consummatamque senectam

non ferro finire pudet: tali ordine uitae

ciues Martis agunt ...

Yours is the land of the Thracians, which bears Rhodope and Haemus, a land fertile in heroes. (35) Here ice welcomes newborn children and the city's snow hardens the tender limbs of infants from the moment they leave their mothers' womb. Hardly any of them is fed at the breast; rather he is pulled away from the teat and drinks $<$ blood $>$ through a horse's wound. Thus, by abandoning milk, the entire race drinks in its virtue. They have only grown a bit (40) when they soon have mock battles with spears. This game is prompted by the wound that suckled them. As boys, they are skilled at hunting and clear out beasts' dens, and later on, as young men, enriched with plunder, they keep the laws of the sword. And when they have reached ripe old age, it is a disgrace not to end it by the sword. This is the manner of life (45) that the citizens of Mars keep ....

In this passage, Sidonius has transformed the City into the habitat of a nomadic barbarian tribe more reminiscent of Huns and Scythians than of Romans. Admittedly, the Thracians had a reputation for ferocity in antiquity, as Ammianus Marcellinus notes that some of its inhabitants drank blood from skulls (27.4.4). But those times were in the past. The region had settled down under Roman rule, becoming known for its frigid climate $^{36}$ and its excellent crop of strong Roman soldiers. ${ }^{37}$ But rather than simply conveying this information about Anthemius' origins, Sidonius has transformed the Thracians into barbaric northerners, akin to Huns.

The model of Sidonius' brief ethnography is Virgil's description of the barbaric Rutulians in the Aeneid (9.598-620). ${ }^{38}$ Like northern barbarians, the Rutulians dunk their children in ice-cold river waters to harden them, and they practise hunting and horseback-riding from an early age. But Sidonius has intensified this image for Constantinople, as Thracians are hardened by the snow and mount their horses from the cradle. In this, they are reminiscent of nomadic barbarian peoples as described by

35 Only John Malalas, Chronicle 13.7 gives the city a Thracian origin. Malalas is cited according to J. Thurn, Ioannis Malalae chronographia (Berlin, 2000).

${ }^{36}$ Pompon. 15, 17; Claud. Stil. 23; Ruf. 1.241-2; Paulinus of Nola, Ad Nicetam 205-17. Paulinus is cited according to F. Dolveck, Paulini Nolani Carmina (Turnhout, 2015).

37 Expositio Totius Mundi et Gentium 50. The Expositio is cited according to J. Rougé, Expositio Totius Mundi et Gentium: introduction, texte critique, traduction, notes et commentaire (Paris, 1966).

38 On the Rutulians, N. Horsfall, 'Numanus Remulus: ethnography and propaganda in "Aen.", ix, 598 f.', Latomus 30 (1971), 1108-16; R. Jenkyns, 'Pathos, tragedy and hope in the Aeneid', JRS 75 (1985), 60-77. 
Ammianus Marcellinus, Claudian and Sidonius himself. ${ }^{39}$ Sidonius elsewhere explicitly associates traits such as the Thracians' drinking horseblood for milk with the Getae (Goths, presumably). ${ }^{40}$ Some intellectuals may have assumed that the Thracians were similar to northern barbarians because of their cold climate. ${ }^{41}$ But curiously, Sidonius also gives no hint that his imagined Thracians are a thing of the past, and even makes them more vividly present for the reader through the use of present-tense verbs. As he also refers to the city's snows (nix ciuica) that hardens the Thracians' limbs, one is led to believe that his barbaric Thracians are a lived reality of Constantinople. Thus, in discussing his subject's origins, Sidonius effectively wraps up Anthemius in rhetorical barbarian furs.

Throughout his panegyric, Sidonius does not let up on associating Anthemius with barbarians. He has already established Anthemius' inurement to the cold, as we can reasonably assume from his description of the Thracians that Anthemius was hardened by the city's snows. In what follows, Sidonius describes Anthemius' youth, recounting how as a boy Anthemius played the game (ludus) of stringing the bow, hurling the spear, riding the horse, and hunting wild beasts. ${ }^{42}$ In a different context, these would look like the typical pastimes of a Roman aristocrat. However, after Sidonius has described the youthful customs of the Thracians, one cannot help noticing the neat parallelism between young Thracians and the child Anthemius. Anthemius is simply acting and behaving just like a Thracian youth.

However, Sidonius does not include a scene where a barbarian recognizes the emperor's superiority, at least not a scene so obvious as in his panegyrics of Avitus and Anthemius. After introducing Anthemius' origins and upbringing, Sidonius turns to his accomplishments, describing how he defeated an army of pillaging Huns near Serdica in the winter of 466-7. Sidonius' narrative of this event includes a description of the Huns, which we should read alongside his earlier description of the Thracians. I reproduce it here, omitting Sidonius' description of the Huns' fearsome facial features for the sake of space:

albus Hyperboreis Tanais qua uallibus actus

Riphaea de caute cadit, iacet axe sub ursae

gens animis membrisque minax ...

...

uix matre carens ut constitit infans, mox praebet dorsum sonipes; cognata reare membra uiris: ita semper equo ceu fixus adhaeret rector; cornipedum tergo gens altera fertur, haec habitat. teretes arcus et spicula cordi, terribiles certaeque manus iaculisque ferendae mortis fixa fides et non peccante sub ictu edoctus peccare furor.

Where the white Tanais, driven down from the far northern valleys, falls from the Riphaean crag, there dwells in the region of the Bear a race that threatens with its spirit and limbs ...

39 Endurance of the cold: Amm. Marc. 31.2.4; Claud. Ruf. 1.326-7. Horseback-riding from the cradle: Amm. Marc. 31.2.30; Sid. Apoll. Carm. 2.262-4.

40 Sid. Apoll. Carm. 7.83-4.

${ }^{41}$ Gal. De temp. 1.627 discusses the similarity of the Celts, Germans, Scythians and Thracians with regard to hair colour because of their cold climate. Thus, the Thracians could have been contaminated by stereotypes of northern barbarians.

42 Sid. Apoll. Carm. 2.138-48. 
An infant has hardly learned to stand without the aid of his mother, when a horse offers its back. You would think the limbs of man and horse were born together, so firmly does the rider stick to the horse. Any other people is carried on horseback: this people lives there. Rounded bows and arrows are dear to them. Sure and terrible are their hands and firm is their confidence that they will bring death with their javelins. Their fury is trained to do wrongful deeds with blows that never go miss. ${ }^{43}$

Read against the Thracians, Sidonius' Huns share a number of similar traits with them, such as (presumably) endurance of the cold, since they live in the lands of the far north. They also quickly leave a mother's arms to take to a horse's back and exhibit their own extraordinary warlike ability. When Anthemius and his army face the Huns in the text that follows, the clash concerns who is superior: the barbarian northerners or Anthemius the Romano-Thracian commander? Unsurprisingly, Anthemius proves that he can be more terrifying than a race 'barbarous even in the eyes of the barbarians who lived around it' (Carm. 2.240-1). When the Huns charge, Anthemius, his soldiers' Mars, proves even more terrifying to them through his battlefield discipline (Carm. 2.279-80). If Anthemius was perceived as more frightening than the Huns, he was more terrifying than the most terrifying of all the barbarian peoples. In this way, Sidonius emphasizes his ferociousness and how he outperforms barbarians.

\section{ENTER THE BARBARIAN KINGDOMS}

One does not usually think of panegyric as a dynamic genre open to radical change. But, as we have argued above, there was a real shift in Roman constructions of leadership in response to the existential threat posed by barbarians. When their physical strength was threatened, Roman panegyrists increasingly portrayed their leaders in more extreme and barbarian-like ways, emphasizing their extreme endurance of the cold and their youthful bellicosity. Critically, barbarians also had to approve an emperor's physical strength. This revised model of leadership understandably did not survive the end of the empire. When barbarians took the place of the emperor, they needed to swap their metaphorical furs for a toga in order to appeal to Roman audiences. Paradoxically, it was under barbarian rulers that Roman panegyric returned to more conventional imagery. For example, Ennodius, the panegyrist of Theoderic the Ostrogoth, celebrates the fact that 'neither the cold of Scythia, nor Meroe and the tropic of Cancer panting with heat' were unknown to his king. ${ }^{44}$ Similarly, rather than praising his leader's youthful warlikeness, Ennodius describes instead his knowledge of Greek and his upbringing as a Roman gentleman in Constantinople. ${ }^{45}$ Thus, the Roman strove to imitate the barbarian's strength, and the barbarian the Roman leader.

We can push the meaning of this shift in rhetoric further. The way in which one constructs his or her rhetorical position with regard to the perceived other can have profound consequences. Take as a comparandum how the Byzantines (that is, the later Romans) portrayed themselves in relation to their western enemies in the twelfth to fifteenth centuries. In his examination of the issue, Charis Messis has argued that the Byzantines intellectually undermined themselves. In Byzantine formulations of

43 Sid. Apoll. Carm. 2.243-5, 2.262-9.

44 Ennodius, Panegyricus 7, 9. Ennodius is cited according to the edition of C. Rohr, Der Theoderich-Panegyricus des Ennodius (Hannover, 1995).

45 Ennodius, Panegyricus 11-15. 
virtues and vices, westerners possessed predominantly masculine vices in opposition to the Romans' softer virtues. And thus, because the masculine dominates the feminine, these Romans set themselves up to be dominated by Italians and Franks, who carved principalities out of the shattered eastern empire and significantly weakened its response to Turkish conquest. ${ }^{46}$

The Roman emperors of the West arguably set themselves up for a similar intellectual trap as that which subsequently befell their eastern brethren. In this case, it was not the binary masculine vs feminine at stake, but Roman vs barbarian northerner. By increasingly portraying their emperors in a more barbaric fashion and by including a scene in which barbarians approved a leader's physical strength, western Roman pangyrists conceded that formerly 'balanced' Roman strength was no longer adequate on its own. Granted, Roman environmental theory had implicitly conceded that Rome's middle-of-the-road strength was inferior on a brute level to that of northerners, and had recommended that they be subdued with stratagems. But when they portrayed their leaders as exclusively tolerant of the cold and more warlike, panegyrists eroded the dividing line between Romans and barbarians. Making barbarian recognition of Romans' strength a crucial component of their texts, panegyrists implicitly gave barbarians a superior position as witnesses and arbiters of Roman martial virtue, even if emperors were supposed to be their superiors. Encouraged by this propaganda, Roman elites probably thought that a leader needed to have more barbarian traits to succeed and command the respect of their armies. However, as Rome's native leaders were unable to transform their propagandists' words into lasting military and political strength during the last thirty years of native Roman rule, elites must have asked the question: after so many failed Roman emperors posing like barbarians, why not settle for Romanized barbarians such as Odoacer and Theoderic, who naturally had the necessary northern strength needed to rule?

There were of course many other real-world factors that transformed the western Roman empire during this period, ending native rule. But changes in Roman rhetoric and ideology, which were both swept up in and contributed to this process, help us elucidate this transformation.

Bilkent University

SCOTT KENNEDY

scott.kennedy@bilkent.edu.tr

${ }^{46}$ C. Messis, 'Lectures sexuées de l'altérité: Les Latins et identité romaine menacée pendant les derniers siècles de Byzance', JOB 61 (2011), 151-70. 